Hafiz ABDUL BASIT, B.Sc. ${ }^{1}$

E-mail: abdul.bsce141@iiu.edu.pk

Afaq KHATTAK, Ph.D. ${ }^{2}$

(Corresponding author)

E-mail: khattak@tongji.edu.cn

Qalab ABBAS, B.Sc. ${ }^{1}$

E-mail: qalab.bsce142@iiu.edu.pk

Sardar ARSALAN ABBAS, B.Sc. ${ }^{1}$

E-mail: sardar.bsce149@iiu.edu.pk

Arshad HUSSAIN, Ph.D. ${ }^{3}$

E-mail: drarshad@nit.nust.edu.pk

${ }^{1}$ Department of Civil Engineering

International Islamic University

Sector H-10, Islamabad, Pakistan

2 The Key Laboratory of Road and Traffic Engineering

Ministry of Education, Tongji University

4800 Cao'an Road, Jiading, Shanghai, 201804, China

${ }^{3}$ NUST Institute of Civil Engineering

National University of Sciences and Technology

Sector H-12, Islamabad, Pakistan
Safety and Security in Traffic Original Scientific Paper Submitted: 28 Apr. 2021 Accepted: 17 Aug. 2021

\title{
ASSESSMENT OF RISK-TAKING BEHAVIOUR OF YOUNG MOTORCYCLISTS AT UN-SIGNALISED INTERSECTIONS - A PARTIAL LEAST SQUARE STRUCTURAL EQUATION MODELLING APPROACH
}

\section{ABSTRACT}

At un-signalised at-grade intersections or roundabouts, motorcyclists have to make a quick decision to manoeuvre and avoid crash. Many studies show that risk-taking behaviour is the major cause of accidents in young motorcyclists. In this study, we analysed various factors that are involved in the risk-taking behaviour of young motorcyclists at un-signalised intersections. Online questionnaires were distributed among university and college students in Islamabad and Rawalpindi. The data of 490 respondents were collected to test the research model. Partial least square structural equation modelling approach was used to evaluate the measurement model, structural model and importance-performance map analysis. In this study, we assumed that risk-taking behaviour of young motorcyclists at un-signalised intersections could be influenced by several factors, i.e., demographic, past crash involvement, and peer influence. The results revealed that past crash involvement, confidence level, and peer influence were the significant factors that affect the risk-taking behaviour. Peer influence has the highest effect on the risk-taking behaviour. The person whose friends encourage them to take risk and accept challenges is more likely to exhibit the risk-taking behaviour. Those people who are more confident while riding a motorcycle are more likely to take risks.

\author{
KEYWORDS \\ motorcyclists; risk taking behaviour; PLS-SEM; \\ un-signalised intersection.
}

\section{INTRODUCTION}

The un-signalised intersections are defined as any at-grade junction of two or more roads at which the right-of-way for motorists, bicyclists, and pedestrians is not controlled by a highway traffic signals. These locations are designated for vehicles to turn in various directions in order to reach their destinations. Its primary function is to direct vehicles in the proper direction. On any highway, un-signalised intersections are complex locations due to the fact that cars travelling in opposite directions want to share the same room at the same time. Furthermore, pedestrians seek the same space for crossing. At an un-signalised intersection, drivers must make split-second decisions based on their route, intersection geometry, speed and direction of other vehicles and so on, and a slight blunder in judgment may result in serious accidents.

There could be several other factors involved in accidents, especially motorcycles at un-signalised intersection such as rush hours, job stress, arriving on time, etc. Several studies on traffic accidents show 
that four type of crashes are the most prevalent, i.e., sharp-end, angle collisions, side turns, and risky driving accidents $[1,2]$. Among these four types, risky driving and angle accidents are more dangerous causing death or severe injuries, whereas the other two (side turns and sharp-end crashes) are less fatal and mainly cause material damage. If an intersection is signalised, then it will be beneficial for traffic safety, while on the other hand, un-signalised intersections are very dangerous for traffic movement even during non-peak hours. Moreover, the ratio of accidents on roads is directly related to the presence of number of lanes. The total number of crashes can be minimised by providing separate lane for left and right turn at intersections [1].

Several studies about transport psychology and personality characteristics show that risk-taking behaviour (RTB) is the main cause of accidents among young motorcyclists [3, 4]. According to the Five-Factor Theory of personality, the emotional mental state of a person is directly associated with the RTB of motorcyclists [5]. The result of such studies indicates that people with low levels of emotional stability exhibit both anxious and aggressive driving styles more often than the others [6]. Anxiety is also one of the key factors in RTB because it has an impact on our normal cognitive functioning. There is an evidence of a direct relation between anxiety and RTB so far. Normal anxiety does not affect the RTB of drivers while very low or high levels have an adverse effect and lead to risky behaviour [7].

In this research, our aim is to assess various factors affecting the RTB of young motorcyclist at un-signalised intersections using the partial least square structural equation modelling (PLS-SEM) approach. Despite various model specifications and assumptions, traditional modelling techniques such as t-test, ANOVA, and linear regression mainly at- tempted to incorporate RTB of motorcyclists (dependent variable) and social and demographic factors (independent variables) into a statistical model to build a direct relationship between dependent and independent variables [3]. However, some explanatory variables may impact RTB of young motorcyclist indirectly, through one or more mediating variables and thus examining the relationship among explanatory variables can become a difficult and complex task. The PLS-SEM is a statistical method, accounting for dynamic interactions between endogenous variables (i.e., variables that can be regressed on other variables) and exogenous variables (i.e., variables that are simultaneously independent). The model includes latent (unobserved) variables whereas traditional techniques can only analyse the measured variables [8]. Therefore, specifically in this study, a PLS-SEM is formulated to explore the impact of various latent variables such as peer influence, parental and spouse guidance, and traffic law enforcements, etc. on RTB of young motorcyclists at an un-signalised intersection.

Some other modelling approaches such as artificial neural networks (ANN), Bayesian neural networks (BNN), and Support Vector Machines (SVM) are also widely used in traffic and transportation safety research. These methods are essentially non-parametric, and no prior assumptions about the data distribution are required. They are even more statistically accurate than conventional parametric models. However, as compared to the PLS-SEM framework, the major disadvantages of these methods are their complex estimation procedure, black-box format, and complex interpretation of the qualified parameter. A simple SEM model is shown in Figure 1.

Many researchers worked on the relationship between RTB and motorcycle accidents. RTB is a major factor contributing to motorcycle accidents [3].

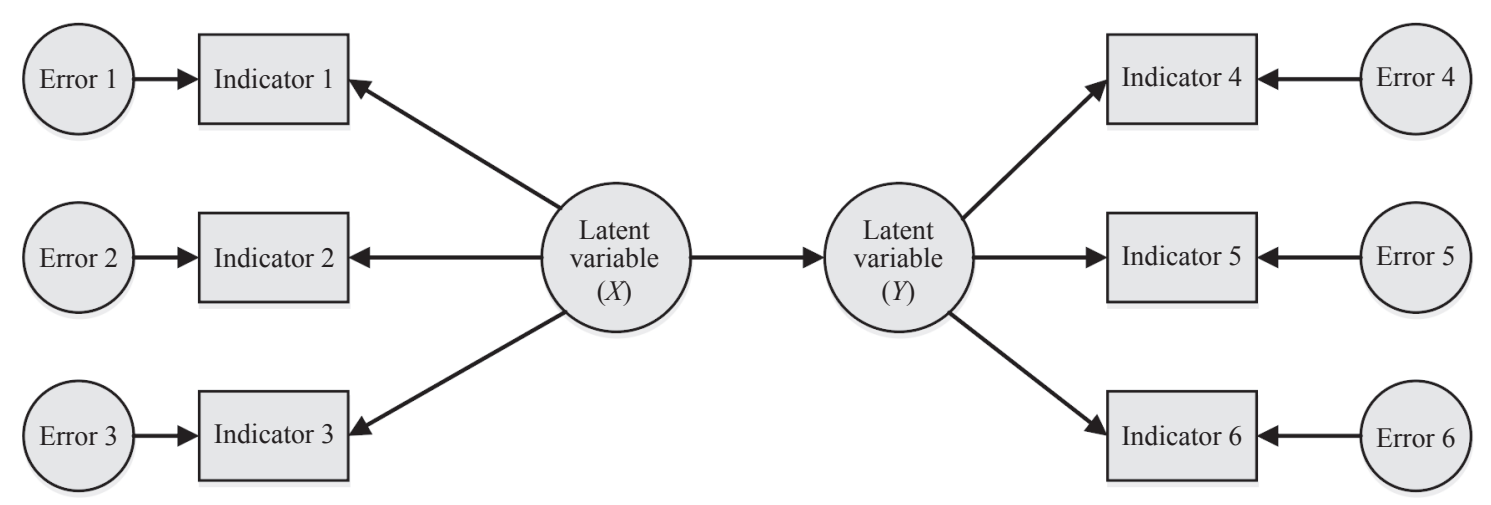

Figure 1 - Simple SEM model 
A motorcycle accident is a major concern of researchers as it has a higher rate of injuries and fatalities [9]. Personality traits have been involved in RTB [10]. Studies have shown that there is a relationship between temperament and RTB during a ride. At intersections in Singapore from 2001 to $2005,54 \%$ of the accidents occurred due to motorcycle users [11]. Impatient riders not only do not avoid high risk but also try to save time by dangerous overtakes [12]. A study in Indonesia showed that in 2012, 72\% of all accidents occurred due to motorcycles and most of them were fatal [9]. Motorcyclists have a higher rate of fatalities than non-motorcycle users [13]. Behaviour varies depending on the social norms, demographic group, and past experience [3].

Behavioural factors contribute to $95 \%$ of traffic accidents while $80 \%$ of road accidents in Thailand involve motorcycle accidents [14]. Fatalities of motorcyclists are 30 times higher than non-motorcycle users for the same travelled distance. The increasing number of motorcycle accidents is due to the willingness of motorcyclists to take risk [15]. Less experience and deficient driving skills contribute to taking a risk. People who started taking rider lessons were more likely to be involved in an accident [16]. Also, male riders of a young age are more likely to take a risk [13]. The risky driving behaviour of young motorcyclists is due to three primary personality traits which are searching for sensation, amiability, and impatience [4]. Motorcyclists at the age 16-25 and having less knowledge are more likely to show RTB at intersections. Many social factors like peer influence, community sentiment, and parental and spouse guidance have a significant effect on RTB [3].

The behaviour of drivers and traffic characteristics were analysed to identify motorcycle accident scenarios. The results showed that the illegal behaviour of motorcyclists is the major factor in road accidents [17]. The research on violation of traffic rules by young motorcyclists found that, in Indonesia, RTB is more prominent in young motorcyclists as compared to older drivers [18]. A study on non-serious behaviour of motorcyclists, like the use of mobile phone while riding, resulted in $40 \%$ of them experiencing accidents and 24\% getting injured [19]. A study on the risk factors associated with motorcycle accidents for older drivers showed that the drivers with riding speed more than $41 \mathrm{~km} / \mathrm{h}$ were more likely to be involved in a crash [20].
A research on the human risk factors and causes of accidents among motorcyclists showed that behaviour of traffic violation of motorcycle riders is the major factor contributing to road accidents [21]. Several factors cause road accidents but human behaviour alone is responsible for $80 \%$ of them [22]. The study of risky behaviour of motorcyclists in Malaysia showed that the most risky behaviour of motorcyclists was turn signal neglect [23]. Motorcyclists are more involved in violation of traffic rules as compared to car drivers [24]. A study on risky riding behaviour of motorcyclists in Iran showed that the factors like low age, less experience, marital status, and low education caused risky behaviour among motorcyclists [25].

Our study aims to determine significant factors affecting RTB using the PLS-SEM approach. SEM is used to develop a relationship between individual and organisational factors that affect temporary worker's safety behaviour using SEM [26]. SEM was adopted to analyse traffic accident intensity for Korean highway [8]. SEM was adopted to develop a quantitative intersection aggressiveness propensity index. The index was planned to compute the overall inclination towards antagonistic driving that was to be experienced at a given signalised intersection [27]. SEM was adopted to represent a correlation between socio-demographics, activity participation, and travel behaviour for every day in a week in developing countries [28].

The rest of the paper is structured as follows. Section 2 contains research methodology including development of hypothesis and research model, site selection, and sample and data collection. Section 3 contains results and discussion. Finally, conclusions are drawn from our research and future work is proposed.

\section{RESEARCH METHODOLOGY}

In this section, we discussed the hypothesis development and research model, site selection, sample data collection, and data screening and pre-analysis.

\subsection{Hypothesis development and research model}

In our current research, the theoretical model is examined as illustrated in Figure 2. It is suggested that risk taking behaviour (RTB) of young motorcyclist is influenced by seven factors (i.e., 


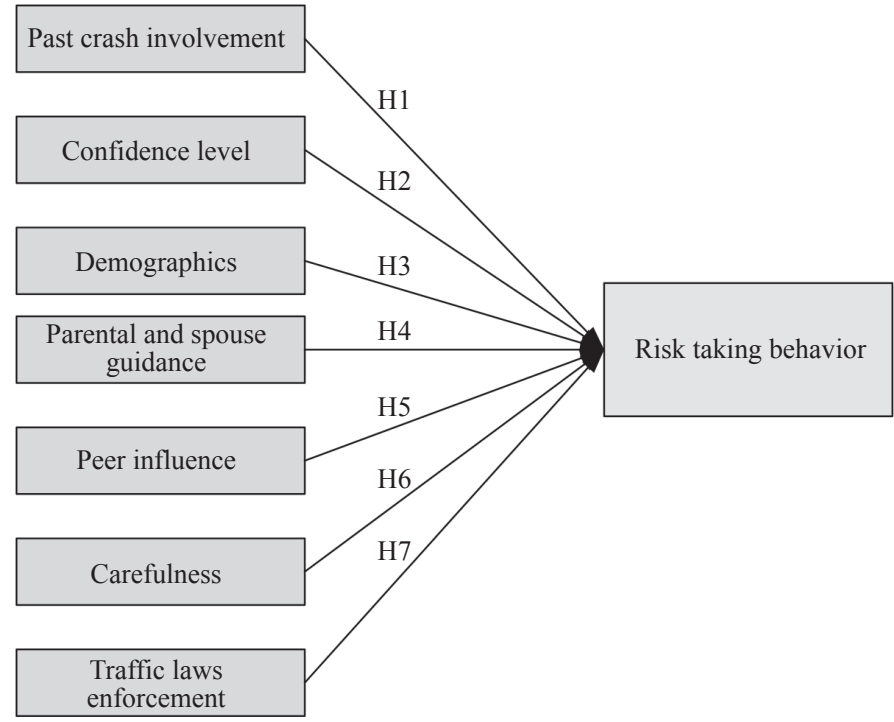

Figure 2 - Conceptual Research Model

demographics, past crash involvement, peer influence, parental and spouse guidance, traffic law enforcement, carefulness and confidence level of riding). Hypothesis for each factor is as follow:

H1: Did past crash involvement have an effect on the RTB of young motorcyclist at un-signalised intersections?

H2: Did confidence level of motorcyclist have an effect on the RTB of young motorcyclist at un-signalised intersections?

H3: Did demographic factors have an effect on the RTB of young motorcyclist at un-signalised intersections?

H4: Did parental and spouse guidance have an effect on the RTB of young motorcyclist at un-signalised intersections?

H5: Did peer influence have an effect on the RTB of young motorcyclist at un-signalised intersections?

H6: Did carefulness have an effect on the RTB of young motorcyclist at un-signalised intersetions?

H7: Did traffic laws enforcement have an effect the RTB of young motorcyclist at un-signalised intersections?

\subsection{Site selection}

The cities selected for this study are Islamabad and Rawalpindi. Islamabad is the capital of Pakistan while Rawalpindi is its neighbouring city, and these two cities are jointly known as the "twin cities" due to strong socio-economic links between them. Several private and public universities as well as colleges are located in these cities in which most of the students use motorcycle as their mode of transport. These cities are selected as they are two of the biggest cities of Pakistan and there are several universities in which students from all over Pakistan are studying. Students use motorcycles as it is a cheap mode of transportation. The total area of both cities is $479 \mathrm{~km}^{2}$, Islamabad having $220 \mathrm{~km}^{2}$ and Rawalpindi having $259 \mathrm{~km}^{2}$. According to the 2017 census, the total population of the two cities is $3,113,056$ with a density of $6500 / \mathrm{km}^{2}$. The population of Islamabad alone is 1,014,825 and of Rawalpindi 2,098,231.

\subsection{Sample and data collection}

The objective of the current study is to investigate the effect of various factors affecting the RTB of young motorcyclists at un-signalised intersections. In order to attain our objective, the target population for this research were college and university students in the twin cities, i.e., Islamabad and Rawalpindi. Determining the required sample size is an important step for ensuring the accuracy and rigour of any analysis. [29] recommended the 10 times law, which we also adopted for the determination of a minimum sample size in the PLS-SEM analysis. According to the 10 times law, a minimum sample size should be 10 times the largest number of structural paths directed at a given construct in a structural model. In this study, the structural model involves a total eight constructs (i.e., one dependent variable and seven independent). Therefore, as per 10 times law criterion, the sample 


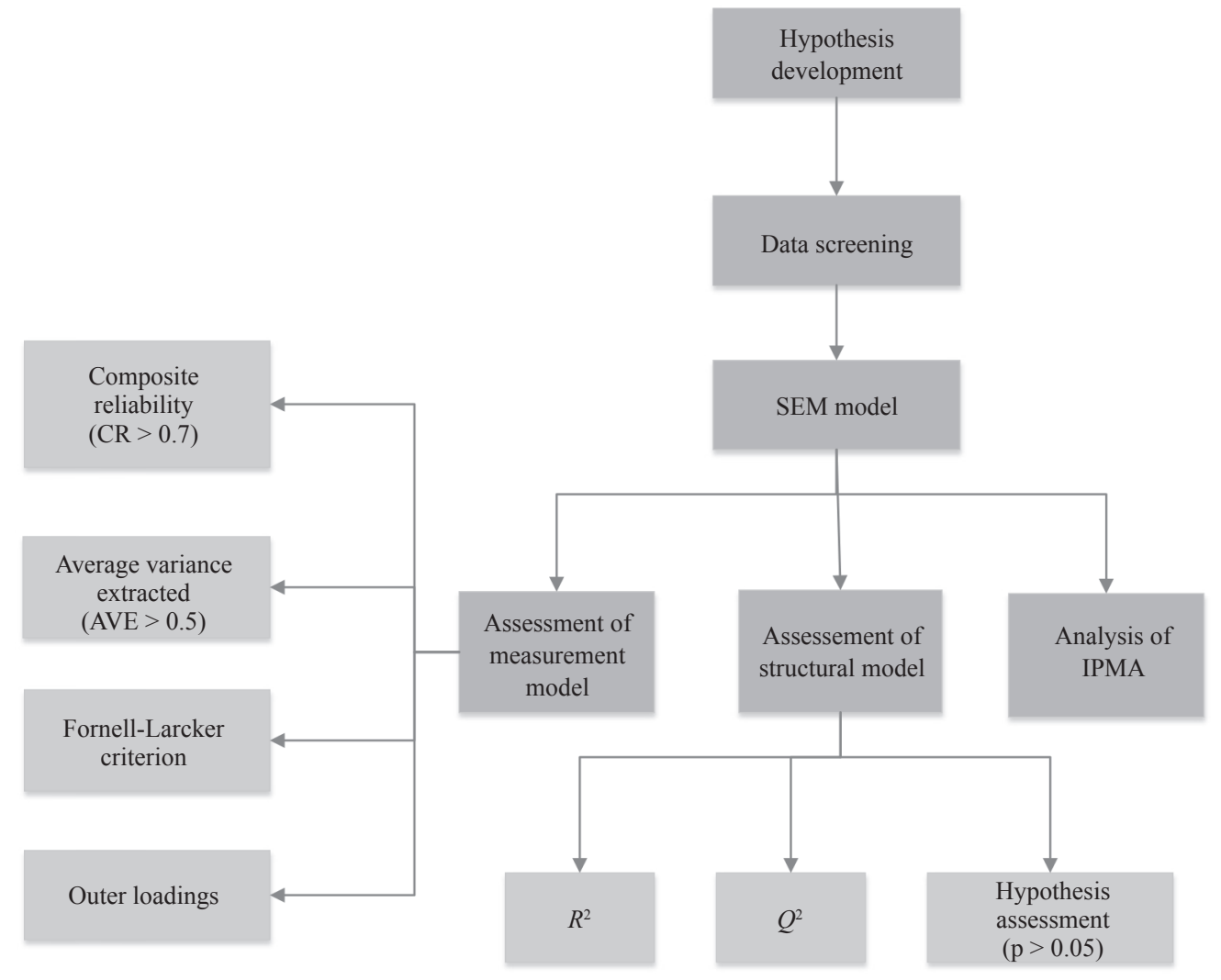

Figure 3 - Algorithm of the performed steps

size in this study should be at least eighty respondents. We however, implemented a more stringent sampling criterion.

The required data was collected using a self-administered survey questionnaire. The questionnaires were distributed to different college and university students using a convenience sampling process in twin cities (Islamabad and Rawalpindi) via social media platforms such as Facebook, WhatsApp, and Twitter. A total of 490 people from twin cities have successfully completed the online survey. The online questionnaire survey data is presented in Appendix 1. We have 16 observed variables, which are grouped in the demographic, past crash involvement, peer influence, parental and spouse guidance, traffic laws enforcement, carefulness and confidence level, and independent variables. The risk-taking behaviour (RTB) factors are our dependent variable.

\subsection{Data screening and pre-analysis}

Variance based PLS-SEM approach was adopted in this research study to test the proposed hypothesis due to its capability to estimate very complex models and its relaxed data requirements. In order to prepare data for the assessment of mea- surement and structural model, an in-depth screening process of data was carried out. The entire data were assessed for any possible outliers, statistical error of normality, and missing values. Very few missing values in the data were observed, which were handled by the use of a widely suggested technique of mean replacement. This technique is a built-in feature of the SmartPLS3 software, which replaces missing data points with the average values of all data points of the same indicator. This approach also does not alter our sample size (unlike list-wise deletion and pair-wise deletion); meanwhile, the average values of all variables remain unchanged.

Following a two-step analytical procedure approach, measurement and structural models were assessed. This is then followed by the assessment of the importance-performance map analysis (IPMA). Algorithm of the performed steps is shown in Figure 3.

\section{RESULTS AND DISCUSSION}

This section is devoted to the discussion of various results, which we obtained from the SmartPLS3 software including measurement model, structural model, and importance-performance map analysis (IPMA). 


\subsection{Assessment of the measurement model}

In this research, the reflective measurement model was evaluated to measure the internal consistency reliability. Based on Figure 4, the composite reliability for constructs (PCI, PSG, PI, C, and TLE) are above the minimum threshold value $(0.70)$, while for the constructs (CL and D) they are below the minimum threshold value $(0.70)$ stated by [29]. Furthermore, the matrix tab in Table 1 shows that the composite reliability value appeared to be 0.74 (PCI), 0.12 (CL), 0.27 (D), 0.75 (PSG), 0.83(PI), $0.71(\mathrm{C})$, and 0.80 (TLE). Table 1 shows that the average variance extracted (AVE) value of PI (.72) is beyond the required lowest threshold value of 0.50 stated by [29]. This is also applicable to PCI $(0.58)$, PSG (0.60), C (0.50), and TLE (0.67). By referring to Figure 4, the respective bar charts clearly indicate that these five reflective constructs have achieved the minimum threshold value. The last column in
Table 1 shows the Cronbach's Alpha (CA). The cutoff value for CA is 0.6 which is considered acceptable [30]. The CA value for the three constructs D (0.74), PI (0.61), and C (0.69) is above the cut-off value. The $\mathrm{CA}$ value for the remaining constructs did not reach the threshold value. Thus, current research findings show that a certain amount of degree of internal consistency reliability has been achieved.

Furthermore, discriminant validity of the constructs was also tested using the Fornell-Larcker criterion. It is the most widely used technique to evaluate discriminant validity [31]. The results are presented in Table 2 in which the italic values show that the square-root of the average variance extended (AVE) surpassed inter-correlations with other constructs. Table 2 shows the results of the Fornell-Larcker criterion assessment with the reflective construct PCI having a value of 0.77 for the square

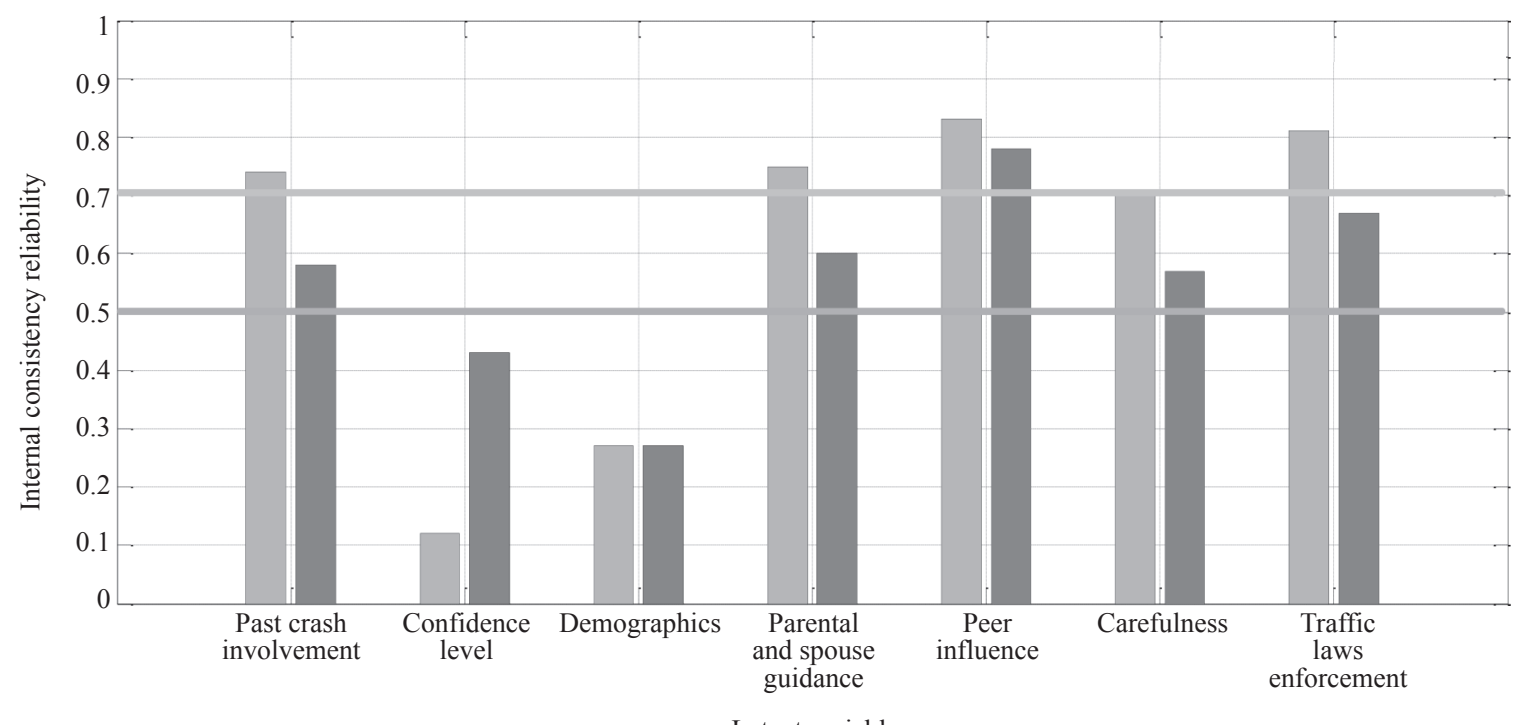

Latent variables

Composite Reliability (CR)

Average Variance Extended (AVE)

Figure 4 - Internal constancy reliability

Table 1 - Internal consistency reliability

\begin{tabular}{||c|c|c|c||}
\hline Variables & Composite reliability (CR) & Average variance extracted (AVE) & Cronbach's alpha (CA) \\
\hline \hline Past crash involvement & 0.74 & 0.58 & 0.30 \\
\hline Confidence level & 0.12 & 0.43 & 0.26 \\
\hline Demographics & 0.27 & 0.27 & 0.74 \\
\hline Parental and spouse guidance & 0.75 & 0.60 & 0.34 \\
\hline Peer influence & 0.83 & 0.78 & 0.61 \\
\hline Carefulness & 0.71 & 0.57 & 0.69 \\
\hline Traffic laws enforcement & 0.80 & 0.67 & 0.52 \\
\hline
\end{tabular}


Basit HA, et al. Assessment of Risk-Taking Behaviour of Young Motorcyclists at Un-Signalised Intersections - A Partial Least...

Table 2 -Discriminant validity (Fornell-Larcker criterion)

\begin{tabular}{||c|c|c|c|c|c|c|c||}
\hline Latent constructs & PCI & CL & D & PSG & PI & C & TLE \\
\hline \hline PCI & 0.77 & & & & & & \\
\hline CL & 0.09 & 0.66 & & & & & \\
\hline D & 0.11 & 0.13 & 0.52 & & & & \\
\hline PSG & -0.09 & 0.03 & -0.03 & 0.77 & & & \\
\hline PI & 0.30 & 0.23 & 0.25 & -0.12 & 0.85 & & \\
\hline C & -0.01 & -0.16 & -0.03 & 0.14 & -0.05 & 0.75 & 0.09 \\
\hline TLE & 0.15 & 0.10 & 0.03 & 0.04 & 0.22 & 0.82 \\
\hline
\end{tabular}

root of its AVE. This value is higher than the CL (0.09), D (0.11), PSG (-0.09), PI (0.30), C (-0.01), and TLE (0.15). As for the reflective construct of CL, it has a value of 0.66 for the square root of its AVE which is greater than D (0.13), PSG (.424), PI (0.23), $\mathrm{C}(-0.16)$, and TLE (0.10). The square root of AVE for $\mathrm{D}$ is 0.52 which is greater than PSG $(-0.03)$, PI (0.25), C (-0.03), and TLE (0.03) and so on.

Meanwhile, Figure 5 depicts all of the indicator's different outer loadings, which correspond to the latent constructs in the measurement model. Most of the indicators in the measurement model have outer loadings values exceeding the threshold value of 0.70 . Other items including $\mathrm{C} 1$ were not removed from the instruments as the AVE value of $\mathrm{C}$ is still well above the minimum requirements.

\subsection{Assessment of the structural model}

In this study, the structural model was evaluated for overall explanatory power of constructs through predictive relevance Stone-Geisser's $Q^{2}$ value, through $R^{2}$ value as well as by path coefficients. For this purpose, the bias-corrected and accelerated (BCA) bootstrapping with 5000 resamples was performed using the PLS-SEM analysis in the SmartPLS3 software. From Table 3 it is observed that the relationship between past crash involvement and risk taking behaviour $(\beta=0.10$; t-statistics $=1.99 ; \mathrm{p}$-value $=.040)$ is significant and has a positive impact; therefore, providing support for H1. It is also supported by the previous study that past crash involvement has an effect on individual

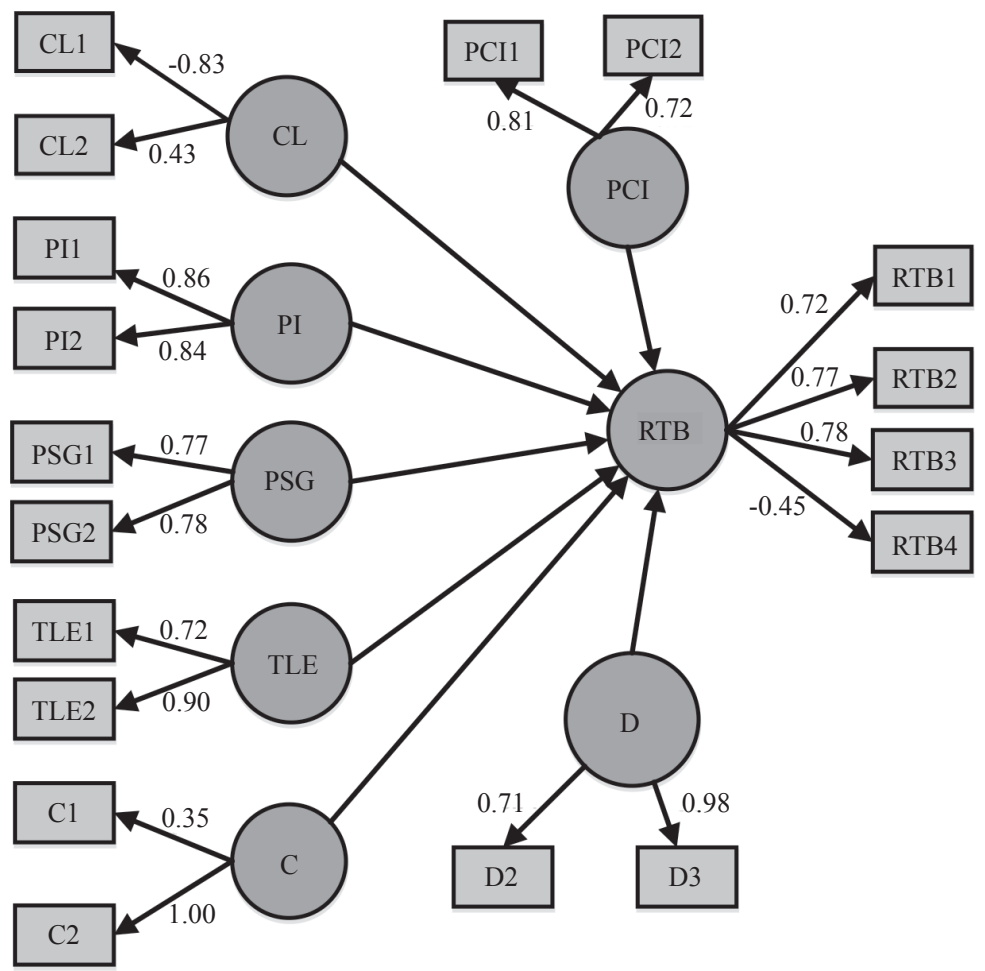

Figure 5 -Outer loading values for the measurement model 
Basit HA, et al. Assessment of Risk-Taking Behaviour of Young Motorcyclists at Un-Signalised Intersections - A Partial Least...

Table 3 - Hypothesis Assessment

\begin{tabular}{||c|c|c|c|c|c||}
\hline \hline Hypothesis & Hypothesised path & $\beta$-value & t-statistics & p-value & Decision \\
\hline \hline H1 & Past crash involvement $\rightarrow$ RTB & 0.10 & 1.99 & 0.04 & Supported \\
\hline H2 & Confidence level $\rightarrow$ RTB & -0.14 & 3.47 & 0.00 & Supported \\
\hline H3 & Demographics $\rightarrow$ RTB & 0.08 & 1.89 & 0.06 & Not supported \\
\hline H4 & Parental and spouse guidance $\rightarrow$ RTB & -0.04 & 0.89 & 0.37 & Not supported \\
\hline H5 & Peer influence $\rightarrow$ RTB & 0.47 & 12.44 & 0.00 & Supported \\
\hline H6 & Carefulness $\rightarrow$ RTB & 0.04 & 0.70 & 0.48 & Not supported \\
\hline H7 & Traffic laws enforcement $\rightarrow$ RTB & 0.05 & 1.20 & 0.23 & Not supported \\
\hline
\end{tabular}

attitude [32-34]. Likewise, H2, which is a relationship between confidence level and risk taking behaviour $(\beta=-0.14 ; \mathrm{t}$-statistics $=3.47$; $\mathrm{p}$-value $=0.00)$, is significant and also supported. Similarly, the relation between Peer Influence and RTB $(\beta=0.0 .47$; $\mathrm{t}$-statistics $=12.44 ; \mathrm{p}$-value $=0.00)$ is also significant and thus H5 is also supported. This result confirms the finding of the previous study that peer influence is a dominant factor affecting RTB [3]. Surprisingly, demographic $(\mathrm{H} 3)(\beta=0.08$; t-statistics $=1.89$; $\mathrm{p}$-value $=.006)$ parental and spouse guidance $(\mathrm{H} 4)$ $(\beta=-0.04$; -statistics $=0.89$; $p$-value $=.037)$, carefulness $\mathrm{S}(\mathrm{H6})(\beta=0.04 ; \mathrm{t}$-statistics $=0.70 ; \mathrm{p}$-value $=0.48)$ and traffic laws enforcement $(\mathrm{H} 7)(\beta=0.05$; t-statistics $=1.20 ; \mathrm{p}$-value $=.023$ ) did not translate into RTB. Therefore; H3, H4, H6 and $\mathrm{H} 7$ were not supported.

Moreover, the value of $R^{2}$ in Figure 6 illustrates that the seven factors: demographics, past crash involvement, peer influence, parental and spouse guidance, traffic law enforcement, carefulness and confidence level of riding together explained $45.1 \%$ of the variance in RTB $\left(R^{2}=0.451\right)$. This shows that our proposed conceptual model has a satisfactory explanatory significance. However, for supporting a model, it is pertinent to mention that having only $R^{2}$ value is not a good approach. Therefore, Stone-Geisser's $Q^{2}$ value has also been used for assessing the predictive relevance of our proposed structural model. If the value of Stone-Geisser's $Q^{2}$ is larger than zero, it indicates that our values are well reconstructed and that our proposed model has predictive relevance. The value of Stone-Geisser's $Q^{2}$ in our proposed structural model is 0.22 , which supports the basic assumption of the current study. The endogenous construct (i.e., RTB) in the current study has a strong predictive relevance.

\subsection{Assessment of the importance- performance map analysis (IPMA)}

In this study, we also employed the importance-performance map analysis (IPMA) as an advanced technique in PLS-SEM using the risk taking behaviour of young motorcyclists at un-signalised

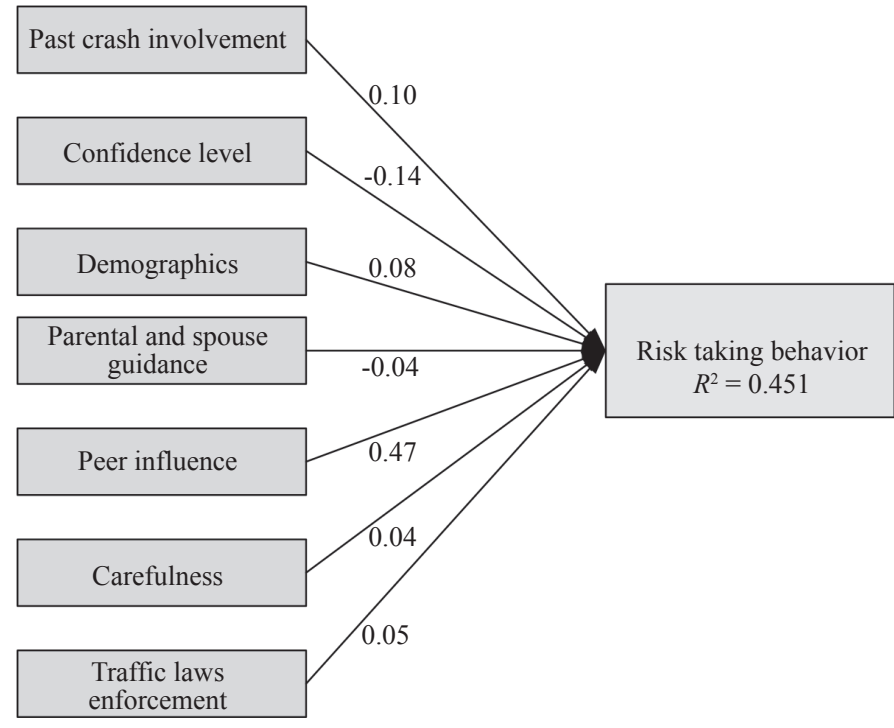

Figure 6-Findings of structural model. 


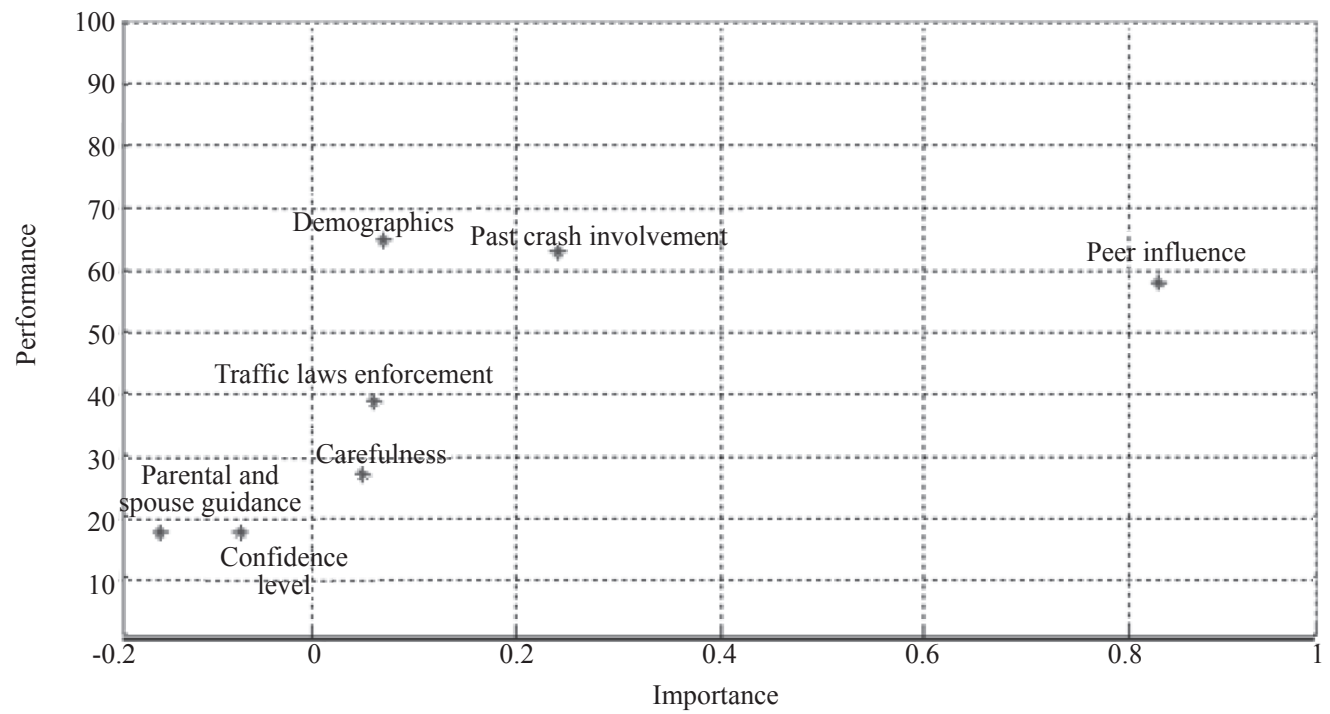

Figure 7 - IPMA for the RTB

intersections as the target construct. The IPMA enriches the understanding of the outcomes of the PLSSEM analysis. IPMA includes the average value of the latent structures and their metrics as a replacement for just looking at the path coefficients. Figure 7 depicts the results of the IPMA. In that, the importance and performance of the seven factors (i.e., acquisition, sharing, application, and protection) were calculated.

While looking at the right-side area of the importance-performance map, it is illustrated that "Peer influence" has a higher importance score, i.e., 0.81; if the friend encouragement or accepting challenges of motorcyclists increases by a single unit point, its' total RTB will enhance by 0.81 . Furthermore, our findings also revealed that RTB has least the least effect on parental and spouse guidance and confidence level, i.e., 16.48 and 17.25 respectively, which means that lower confidence level and proper parental and spouse guidance result in lowering the RTB of motorcyclists. Table 4 shows a complete list of importance-performance values for the ease of readers.

Table 4 - Importance-performance map analysis for RTB

\begin{tabular}{|c|c|c||}
\hline Latent variables & Importance & Performance \\
\hline \hline Past crash involvement & 0.23 & 63.90 \\
\hline Confidence level & -0.07 & 17.25 \\
\hline Demographic & 0.07 & 64.87 \\
\hline Parental and spouse guidance & -0.14 & 16.48 \\
\hline Peer influence & 0.81 & 56.13 \\
\hline Carefulness & 0.04 & 25.48 \\
\hline Traffic laws enforcement & 0.05 & 39.43 \\
\hline
\end{tabular}

\section{CONCLUSION}

In this study, we postulated that accident involvement, peer influence, parental and spouse guidance, traffic law enforcement, prevention steps, and confidence level are exogenous variables for PLS-SEM to analyse the RTB of young motorcyclists at un-signalised intersections. We have employed IPMA, the advanced technique in PLS-SEM. The current research study has several practical implications for the transport policy makers as well as practitioners. The findings of research study are as follows:

- Peer influence, past crash involvement, and confidence level play an important role in determining the RTB.

- Peer influence is the most important factor to explain the RTB and its importance value is 0.81 .

Experienced motorcyclists are more likely to take a risk. Motorcyclists who were involved in past crash are more likely to take risk. Also, those people who properly follows the traffic rules were less likely to take risks at un-signalised intersections. Motorcyclists whose friends encourage them to over speed are more likely to take the risks. Also, those who accept challenges like over speeding from their friends are also more likely to take the risks.

Although the findings of this research study shed light on a number of important issues related to RTB, there are other factors that need to be considered, such as the effect of the type of intersections (signalised/un-signalised), gender effect (male/female), spatial effect (for different cities) etc. This research also has certain limitations, e.g. data is collected only from students and can be applicable 
only to the developing countries such as Sri Lan$\mathrm{ka}$ and Bangladesh as there are more un-signalised intersections. Moreover, in future research, several other vehicle types could be analysed and driving behaviour could be assessed. The results of this study contribute to transport policy development by identifying the key factors affecting the RTB of young motorcyclists. The transport policymakers should focus on the identified factors to reduce crash involvements at intersections.

\section{ACKNOWLEDGEMENT}

We are thankful to all the colleages at the Department of Civil Engineering, International Islamic Unversity Islamabad for their guidance and support in data collection.

$$
\begin{aligned}
& \text { w }
\end{aligned}
$$

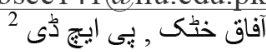

$$
\begin{aligned}
& \text { اى ميل : khattak@tongji.edu.cn }
\end{aligned}
$$

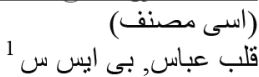

$$
\begin{aligned}
& \text { : qalab.bsce142@,iiu.edu.pk } \\
& \text { سردار ارسلان عباس ،, بى ايس سى } 1 \\
& \text { اى ميل : sardar.bsce149@iiu.edu.pk } \\
& \text { ارشد حسين, بيى ايجز ذُ } 3 \\
& \text { drarshad@nit.nust.edu.pk }
\end{aligned}
$$

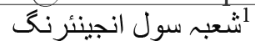

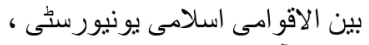

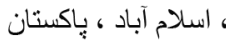

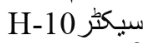

$$
\begin{aligned}
& \text { زرود اور ثريفى انجينئرنى كى كليدى ليبارنز }
\end{aligned}
$$

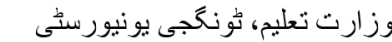

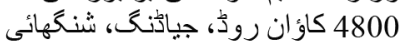

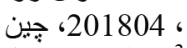

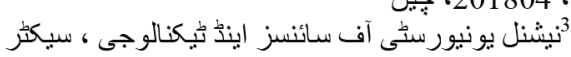

$$
\begin{aligned}
& \text { H-12- } \\
& \text { اسلام آباد ، باكستان }
\end{aligned}
$$

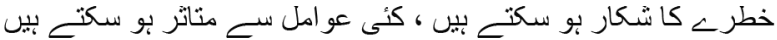

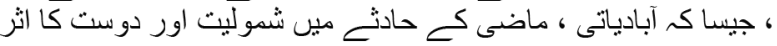

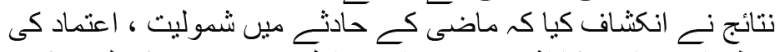

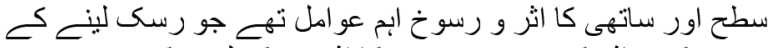

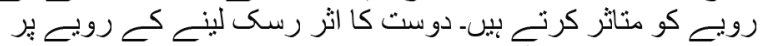

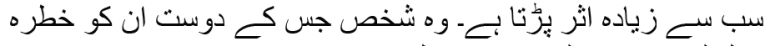

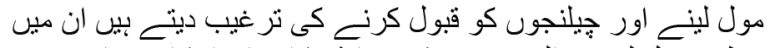

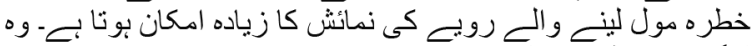

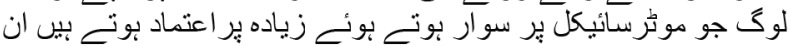

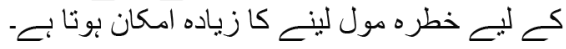

مطلوبت الفاظ: موشر سائيكل سوار ، رسك لينه كا رويم ، جور ابا، ئى ايل ايس- ايس ائ ايم

\section{REFERENCES}

[1] Polders E, et al. Crash patterns at signalized intersections. Transportation Research Record: Journal of the Transportation Research Board. 2015;2514(1): 105116. doi: 10.3141/2514-12.

[2] Duddu VR, Kukkapalli VM, Pulugurtha SS. Crash risk factors associated with injury severity of teen drivers. IATSS research. 2019;43(1): 37-43.

[3] Borhan MN, Ibrahim ANH, Aziz A, Yazid MRM. The relationship between the demographic, personal, and social factors of Malaysian motorcyclists and risk taking behavior at signalised intersections. Accid Anal Prev. 2018;121: 94-100. doi: 10.1016/j.aap.2018.09.004.

[4] Romero DL, de Barros DM, Belizario GO, Serafim AP. Personality traits and risky behavior among motorcyclists: An exploratory study. PLoS One. 2019;14(12): e0225949. doi: 10.1371/journal.pone.0225949.

[5] Soto C, Jackson J. Five-Factor Model of Personality; 2013.

[6] Dahlen ER, et al. Taking a look behind the wheel: An investigation into the personality predictors of aggressive driving. Accident Analysis \& Prevention. 2012;45: 1-9. doi: 10.1016/j.aap.2011.11.012.

[7] Oltedal S, Rundmo T. The effects of personality and gender on risky driving behaviour and accident involvement. Safety Science. 2006;44(7): 621-628. doi: 10.1016/j.ssci.2005.12.003.

[8] Lee J-Y, Chung J-H, Son B. Analysis of traffic accident size for Korean highway using structural equation models. Accident Analysis Prevention. 2008;40(6): 19551963. doi: 10.1016/j.aap.2008.08.006.

[9] Susilo YO, Joewono TB, Vandebona U. Reasons underlying behaviour of motorcyclists disregarding traffic regulations in urban areas of Indonesia. Accid Anal Prev. 2015;75: 272-84. doi: 10.1016/j.aap.2014.12.016.

[10] Totkova Z, Racheva R. A multidimensional method for assessing personality characteristics related to risky driving behavior. Psychol. Res. 2019;22: 746-775.

[11] Haque MM, Chin HC, Huang H. Examining exposure of motorcycles at signalized intersections. Transportation Research Record: Journal of the Transportation Research Board. 2008;2048(1): 60-65. doi: 10.3141/204808.

[12] Wong J-T, Chung Y-S, Huang S-H. Determinants behind young motorcyclists' risky riding behavior. Accident Analysis \& Prevention. 2010;42(1): 275-281. doi: 10.1016/j.aap.2009.08.004. 
[13] Chang H-L, Yeh T-H. Risk factors to driver fatalities in single-vehicle crashes: Comparisons between non-motorcycle drivers and motorcyclists. Journal of Transportation Engineering. 2006;132(3): 227-236. doi: 10.1061/(ASCE)0733-947X(2006)132:3(227).

[14] Hongsranagon P, et al. Traffic risk behavior and perceptions of Thai motorcyclists: A case study. IATSS Research. 2011;35(1): 30-33. doi: 10.1016/j.iatssr.2011.03.001.

[15] Haworth N, Greig K, Nielson A. Comparison of risk taking in moped and motorcycle crashes. Transportation Research Record. 2009;2140(1): 182-187. doi: 10.3141/2140-20.

[16] Savolainen P, Mannering F. Effectiveness of motorcycle training and motorcyclists' risk-taking behavior. Transportation Research Record. 2007;2031(1): 52-58. doi: 10.3141/2031-07.

[17] Chang F, et al. Identifying motorcycle high-risk traffic scenarios through interactive analysis of driver behavior and traffic characteristics. Transportation Research Part F: Traffic Psychology. 2019;62: 844-854. doi: 10.1016/j.trf.2019.03.010.

[18] Joewono TB, Susilo YO. Traffic violations by young motorcyclists on Indonesian urban roads. Journal of Transportation Safety Security. 2017;9(sup1): 236-261. doi: 10.1080/19439962.2016.1247123.

[19] Truong LT, Nguyen HT, De Gruyter C. Mobile phone use while riding a motorcycle and crashes among university students. Traffic Injury Prevention. 2019;20(2): 204-210. doi: 10.1080/15389588.2018.1546048.

[20] Chen S-J, Chen C-Y, Lin M-R. Risk factors for crash involvement in older motorcycle riders. Accident Analysis Prevention. 2018;111: 109-114. doi: 10.1016/ j.aap.2017.11.006.

[21] Harith SH, Mahmud N. Human risk factors and road accident causation among motorcyclists in Malaysia: A review article. Proceedings of the International Conference on Industrial Engineering and Operations Management; 2018.

[22] Fai LC. Miros statistics say human error causes $80 \%$ of traffic accidents. Sun Media Corporation Sdn. Bhd; 2015.

[23] Rusli R, Oviedo-Trespalacios O, Abd Salam SA. Risky riding behaviours among motorcyclists in Malaysia: A roadside survey. Transportation Research Part F: Traffic Psychology Behaviour. 2020;74: 446-457. doi: 10.1016/j.trf.2020.08.031.
[24] Cordellieri P, et al. Driving attitudes, behaviours, risk perception and risk concern among young student car-drivers, motorcyclists and pedestrians in various EU countries. Transportation Research Part F: Traffic Psychology Behaviour. 2019;65: 56-67. doi: 10.1016/j. trf.2019.07.012.

[25] Hassanzadeh K, Salarilak S, Sadeghi-Bazargani H, Golestani M. Motorcyclist risky riding behaviors and its predictors in an Iranian population. Journal of Injury Violence Research. 2020;12(2): 161. doi: 10.5249/jivr. v12i2.936.

[26] Seo H-C, Lee Y-S, Kim J-J, Jee N-Y. Analyzing safety behaviors of temporary construction workers using structural equation modeling. Safety Science. 2015;77: 160168. doi: 10.1016/j.ssci.2015.03.010.

[27] Hamdar SH, Mahmassani HS, Chen RB. Aggressiveness propensity index for driving behavior at signalized intersections. Accident Analysis \& Prevention. 2008;40(1): 315-326. doi: 10.1016/j.aap.2007.06.013.

[28] Chung J-H, Ahn Y. Structural equation models of dayto-day activity participation and travel behavior in a developing country. Transportation Research Record. 2002;1807(1): 109-118. doi: 10.3141/1807-14.

[29] Hair Jr JF, Hult GTM, Ringle CM, Sarstedt M. A primer on partial least squares structural equation modeling (PLS-SEM). Sage Publications; 2021.

[30] Hair J, Black W, Babin B, Anderson R. Multivariate data analysis: Pearson College Division. Pearson Prentice Hall; 2010.

[31] Hair Jr JF, Matthews LM, Matthews RL, Sarstedt M. PLS-SEM or CB-SEM: Updated guidelines on which method to use. International Journal of Multivariate Data Analysis. 2017;1(2): 107-123.

[32] Knight PJ, Iverson D, Harris MF. Early driving experience and influence on risk perception in young rural people. Accident Analysis Prevention. 2012;45: 775-781. doi: 10.1016/j.aap.2011.10.005.

[33] Cheng AS, Ng TC, Lee HC. Impulsive personality and risk-taking behavior in motorcycle traffic offenders: A matched controlled study. Personality Individual Differences. 2012;53(5): 597-602. doi: 10.1016/j. paid.2012.05.007.

[34] Iversen H. Risk-taking attitudes and risky driving behaviour. Transportation Research Part F: Traffic Psychology Behaviour. 2004;7(3): 135-150. doi: 10.1016/ j.trf.2003.11.003. 


\section{Appendix 1}

\begin{tabular}{|c|c|c|c|c|c|}
\hline Factor & Code & Question & Item & Frequency & Percentage \\
\hline \multirow{12}{*}{ 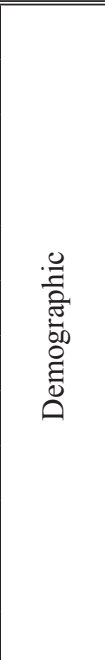 } & \multirow{2}{*}{ D1 } & \multirow{2}{*}{ In which city do you live? } & Islamabad (1) & 243 & 48.6 \\
\hline & & & Rawalpindi (2) & 182 & 47 \\
\hline & \multirow{4}{*}{ D2 } & \multirow{4}{*}{ What is your age? } & $16-18(1)$ & 50 & 12.9 \\
\hline & & & $19-22(2)$ & 205 & 53 \\
\hline & & & $23-26(3)$ & 115 & 29.7 \\
\hline & & & Above 26 (4) & 50 & 12.9 \\
\hline & \multirow{4}{*}{ D3 } & \multirow{4}{*}{ What is your education level? } & Inter (1) & 60 & 15.5 \\
\hline & & & Undergraduate (2) & 196 & 50.6 \\
\hline & & & Graduate (3) & 105 & 27.1 \\
\hline & & & Post Graduate (4) & 26 & 6.7 \\
\hline & \multirow{2}{*}{ D4 } & \multirow{2}{*}{ Do you have a driving license? } & Yes (1) & 117 & 30.2 \\
\hline & & & No (2) & 270 & 69.8 \\
\hline \multirow{4}{*}{ 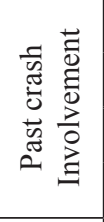 } & \multirow{2}{*}{ PCI1 } & \multirow{2}{*}{$\begin{array}{l}\text { Have you ever been involved in a crash at an un-signalised } \\
\text { intersection or roundabout? }\end{array}$} & Yes (1) & 152 & 39.3 \\
\hline & & & No (2) & 235 & 60.7 \\
\hline & \multirow{2}{*}{ PCI2 } & \multirow{2}{*}{$\begin{array}{l}\text { In the future, would it be expected for you to get involved } \\
\text { in a crash/accidents at any un-signalised intersection or } \\
\text { roundabout, considering the traffic flow of your area? }\end{array}$} & Yes (1) & 132 & 34.1 \\
\hline & & & No (2) & 255 & 65.9 \\
\hline \multirow{6}{*}{ 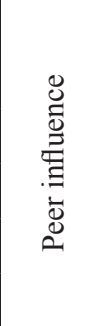 } & \multirow{3}{*}{ PI1 } & \multirow{3}{*}{ Would you accept risk taking challenges from your friends? } & Yes $(1)$ & 82 & 21.2 \\
\hline & & & Sometimes (2) & 119 & 30.7 \\
\hline & & & No (3) & 186 & 48.1 \\
\hline & \multirow{3}{*}{ PI2 } & \multirow{3}{*}{$\begin{array}{l}\text { Do your friends sometimes encourage you to yield and } \\
\text { maintain the same speed when you are approaching an } \\
\text { un-signalised intersection or roundabout, even if you are at } \\
\text { a minor road? }\end{array}$} & Yes $(1)$ & 118 & 30.5 \\
\hline & & & Sometimes (2) & 100 & 25.8 \\
\hline & & & No (3) & 169 & 43.7 \\
\hline \multirow{6}{*}{ 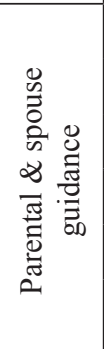 } & \multirow{3}{*}{ PSG1 } & \multirow{3}{*}{ Are your parents aware and know where you go? } & Always (1) & 223 & 57.6 \\
\hline & & & Sometimes (2) & 141 & 36.4 \\
\hline & & & Never (3) & 23 & 5.9 \\
\hline & \multirow{3}{*}{ PSG2 } & \multirow{3}{*}{$\begin{array}{l}\text { Do your parents advise you to ride carefully especially at } \\
\text { an un-signalised intersection or roundabout? }\end{array}$} & Always (1) & 330 & 85.3 \\
\hline & & & Sometimes (2) & 36 & 9.3 \\
\hline & & & Never (3) & 21 & 5.4 \\
\hline \multirow{10}{*}{ 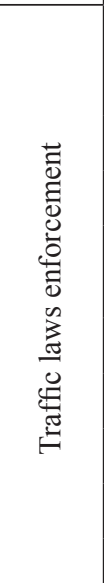 } & \multirow{5}{*}{ TLE1 } & \multirow{5}{*}{$\begin{array}{l}\text { Are police enforcement traffic regulations effective in your } \\
\text { city? }\end{array}$} & Strongly Agree (1) & 72 & 18.6 \\
\hline & & & Agree (2) & 115 & 29.7 \\
\hline & & & Neutral (3) & 120 & 31 \\
\hline & & & Disagree (4) & 40 & 10.3 \\
\hline & & & $\begin{array}{l}\text { Strongly Disagree } \\
(5)\end{array}$ & 40 & 10.3 \\
\hline & & & Very High (1) & 49 & 12.7 \\
\hline & & & High (2) & 101 & 26.1 \\
\hline & TLE2 & $\begin{array}{l}\text { What is the level of risk of being penalised by traffic police } \\
\text { in your city? }\end{array}$ & Normal (3) & 172 & 44.4 \\
\hline & & & Low (4) & 49 & 12.7 \\
\hline & & & Very Low (5) & 16 & 4.1 \\
\hline
\end{tabular}


Basit HA, et al. Assessment of Risk-Taking Behaviour of Young Motorcyclists at Un-Signalised Intersections - A Partial Least...

\begin{tabular}{|c|c|c|c|c|c|}
\hline Factor & Code & Question & Item & Frequency & Percentage \\
\hline \multirow{10}{*}{ 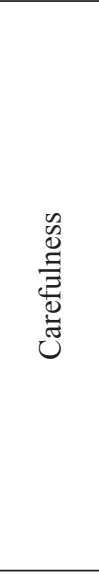 } & \multirow{5}{*}{$\mathrm{C} 1$} & \multirow{5}{*}{ Did you become more careful after the accident? } & Strongly Agree (1) & 145 & 38.7 \\
\hline & & & Agree (2) & 150 & 40 \\
\hline & & & Neutral (3) & 54 & 14.4 \\
\hline & & & Disagree (4) & 18 & 4.8 \\
\hline & & & $\begin{array}{l}\text { Strongly Disagree } \\
(5)\end{array}$ & 8 & 2.1 \\
\hline & \multirow{5}{*}{$\mathrm{C} 2$} & \multirow{5}{*}{$\begin{array}{l}\text { Do you wait at a yield sign when you are at a minor road } \\
\text { and approach an un-signalised intersection or roundabout? }\end{array}$} & Strongly Agree (1) & 141 & 37.4 \\
\hline & & & Agree (2) & 157 & 41.6 \\
\hline & & & Neutral (3) & 56 & 14.9 \\
\hline & & & \begin{tabular}{|l|} 
Disagree (4) \\
\end{tabular} & 14 & 3.7 \\
\hline & & & $\begin{array}{l}\text { Strongly Disagree } \\
(5)\end{array}$ & 9 & 2.4 \\
\hline \multirow{10}{*}{ 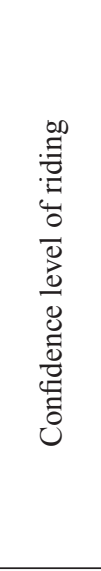 } & \multirow{5}{*}{ CLR1 } & \multirow{5}{*}{$\begin{array}{l}\text { Do you think that you can prevent severe injury by wearing } \\
\text { a motorcycle helmet? }\end{array}$} & Strongly Agree (1) & 152 & 39.3 \\
\hline & & & Agree (2) & 137 & 35.4 \\
\hline & & & Neutral (3) & 59 & 15.2 \\
\hline & & & \begin{tabular}{|l|} 
Disagree (4) \\
\end{tabular} & 32 & 8.3 \\
\hline & & & $\begin{array}{l}\text { Strongly Disagree } \\
(5)\end{array}$ & 7 & 1.8 \\
\hline & \multirow{5}{*}{ CLR2 } & \multirow{5}{*}{$\begin{array}{l}\text { Do you think that experienced riders are less involved in } \\
\text { accidents? }\end{array}$} & Strongly Agree (1) & 89 & 23 \\
\hline & & & Agree (2) & 167 & 43.2 \\
\hline & & & Neutral (3) & 71 & 18.3 \\
\hline & & & Disagree (4) & 44 & 11.4 \\
\hline & & & $\begin{array}{l}\text { Strongly Disagree } \\
(5)\end{array}$ & 16 & 4.1 \\
\hline \multirow{17}{*}{ 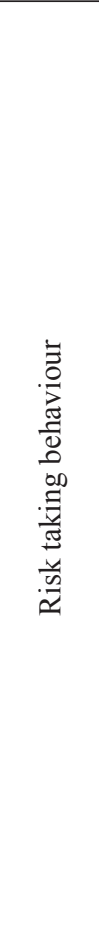 } & \multirow{5}{*}{ RTB1 } & \multirow{5}{*}{$\begin{array}{l}\text { Do you still merge into traffic if you are at a minor road } \\
\text { and there is a yield sign at an un-signalised intersection or } \\
\text { roundabout? }\end{array}$} & Strongly Agree (1) & 80 & 20.7 \\
\hline & & & Agree (2) & 81 & 20.9 \\
\hline & & & Neutral (3) & 81 & 20.9 \\
\hline & & & \begin{tabular}{|l|} 
Disagree (4) \\
\end{tabular} & 97 & 25.1 \\
\hline & & & $\begin{array}{l}\text { Strongly Disagree } \\
(5)\end{array}$ & 48 & 12.4 \\
\hline & \multirow{3}{*}{ RTB2 } & \multirow{3}{*}{ Do you ride at a high speed even if you are not in a hurry? } & Always (1) & 78 & 20.1 \\
\hline & & & Sometimes (2) & 184 & 47.6 \\
\hline & & & Never (3) & 125 & 32.3 \\
\hline & \multirow{5}{*}{ RTB3 } & \multirow{5}{*}{$\begin{array}{l}\text { Do you sometimes not follow the traffic guidelines when } \\
\text { you feel that traffic volume is low at a particular time? }\end{array}$} & Strongly Agree (1) & 57 & 14.7 \\
\hline & & & Agree (2) & 78 & 20.2 \\
\hline & & & Neutral (3) & 107 & 27.6 \\
\hline & & & \begin{tabular}{|l|} 
Disagree (4) \\
\end{tabular} & 98 & 25.3 \\
\hline & & & $\begin{array}{l}\text { Strongly Disagree } \\
(5)\end{array}$ & 47 & 12.1 \\
\hline & \multirow{4}{*}{ RTB4 } & \multirow{4}{*}{$\begin{array}{l}\text { Roughly, how many times did you cross a minor road with } \\
\text { low traffic volume in the past } 2 \text { weeks? }\end{array}$} & Never (1) & 229 & 59.2 \\
\hline & & & 1-5 Times (2) & 101 & 26.1 \\
\hline & & & 6-10 Times (3) & 36 & 9.3 \\
\hline & & & $\begin{array}{l}\text { More than } 10 \text { Times } \\
\text { (4) }\end{array}$ & 21 & 5.4 \\
\hline
\end{tabular}

